\title{
Influence of wind on floating debris distribution in the Balearic Islands
}

\author{
L. Martinez-Ribes ${ }^{1}$, G. Basterretxea ${ }^{1}$, L. Arqueros ${ }^{2}$, A. Jordi ${ }^{1}$, \\ T. Estrany ${ }^{3}$, J. M. Aguilò ${ }^{2} \&$ J. Tintoré ${ }^{1}$ \\ ${ }^{1}$ Mediterranean Institute of Advanced Studies, Balearics, Spain \\ ${ }^{2}$ Coordination Centre for the Quality Plan for Bathing Waters, \\ Environmental Council, Balearics, Spain \\ ${ }^{3}$ Department of Mathematics and Information Technology, \\ Illes Balears University, Spain
}

\begin{abstract}
In this work we analyse the distribution of floatable debris around the Balearics (Spain) during the summer of 2005 (June-September). Litter abundance and distribution was obtained from the registers of 40 cleaning-ships operating daily around the archipelago. A total of $133.671 \mathrm{Kg}$. of debris was collected in the coastal waters of Mallorca, and the main component was wood. Different scenarios of litter dispersal are analysed at selected coastal bays depending on wind direction.

Keywords: Balearics, Mediterranean Sea, floating debris, cleaning, wind effect, tourism.
\end{abstract}

\section{Introduction}

The economy of the Balearic Islands is based on the tourism sector, and tourism activities are mainly related to the recreational use of the coast. Preserving the quality of the coastal waters is, consequently, a major objective of the local government. As part of the maintenance activities carried out in the coastal environment, 40 cleaning boats sweep the $1,400 \mathrm{~km}$ of coastline, collecting floating debris during high tourism season (June to September). This marine litter program requires a strong human effort and an expenditure exceeding 3.5 $\mathrm{M} €$. Cleaning activities are paralleled by a scientific program aimed to detect the origin and distribution of marine debris. It is believed that scientifically based 
knowledge about litter sources and pathways will not only allow the optimization of cleaning efforts but, also, will make possible implementing new palliative strategies and protective policies. Once released into the ocean, floating debris may be concentrated by natural processes along lines of convergent flow, at the core of major current gyres or on beaches and submerged rocky outcrops (Laist [1], Pruter [2]; Galgani et al. [3]). As environmental features affecting the distribution of litter and its arrival to beaches, the direction of wind, surface waves and currents (Shaw and Mapes [4]; Pruter [2]; Thiel et al. [5]; Abu-Hilal and Al-Najjar [6]) are amongst the most relevant. Vauk and Schrey [7] suggest that floating materials at the surface are primarily influenced by winds and only secondarily by currents.

The removal of floating debris from the sea is not only important because of the visual impact that litter produces on users, but also because of the harmful effects it generates in the marine environment and on the activities developed on the coastal waters. Economic losses from marine litter include the fouling of trawl nets by bottom debris, the blocking of water intake pipes by plastic sheeting and damage to ships and recreational boats following collisions with metal drums or wooden pallets at sea, as well as propeller fouling by floating or semi-submerged nylon ropes and net fragments (Dixon and Dixon [8]). As for the marine ecology, several studies point out the importance that litter has on the life of marine animals such as turtles, and how all kinds of species can be affected by its presence. For instance, the ingestion of plastics in sea turtles in the Mediterranean was studied by Tomás et al. [9]), who concluded that more than a $75 \%$ of what was found in turtles' stomachs was composed of plastic. The aim of this work is to analyze the characteristics and distribution of floating debris at two selected bays in Mallorca (Spain) and more specifically, the effects of wind in debris distribution along the coast as given by the positions of the cleaning boats.

\section{Materials and methods}

Herein presented floating debris data was recorded onboard the fleet of cleaning ships operating on a daily basis in the Balearic Islands during summer 2005. Two types of ships are presently used in cleaning tasks; the Virots which stay in the nearshore waters (i.e. $1 / 4$ mile from shore) and the Pelicans, which are able to operate within 4-5 nautical miles from the coast. The GPS position of each unit is visualized and recorded every 3 minutes in the Water Quality Control Office. The routes that the ships follow are selected in terms of sea conditions and litter location information obtained with airborne methods. Collected floating debris is sorted by type of material (i.e. plastics, woods, organic matter, seaweeds and other) and its weight recorded at the end of the day.

As a case study two different bays in Mallorca are selected, Palma and Santa Ponça (see Figure 1). The former is a large bay $\left(\sim 185 \mathrm{~km}^{2}\right)$ beholding the city of Palma, the largest population (476.000 inhabitants in the metropolitan area) and the main port of the islands. Santa Ponça is a smaller embayment $\left(\sim 32 \mathrm{~km}^{2}\right)$ located west of Palma bay, mainly dedicated to tourism activities. Both bays are 
opened to the south west and present a similar wind regime (see Basterretxea et al. [10]). A data set from 9 cleaning boats (6 operating in Palma and 3 in Santa Ponça) containing 73,404 GPS positions has been analyzed. Values corresponding to static ship positions $(<0.5$ knots) and steaming data have been disregarded. Density maps have been produced pooling the data in $200 \times 200 \mathrm{~m}$ grid cells and standardizing the results of each case by the total number of data. The final data set for each area has been divided attending to the prevailing wind conditions of each day. Meteorological data for the area was obtained from the Spanish National Institute of Meteorology (INM). The wind data was divided in 90 degree sectors based on the mean wind vector direction for the first 12 hours of each day. Direction 1 stands for winds coming from $0^{\circ}$ (North) to $90^{\circ}$ (E); direction 2 for winds from $91^{\circ}$ to $180^{\circ}$; direction 3 from $181^{\circ}$ to $270^{\circ}$ and direction 4 from $271^{\circ}$ to $359^{\circ}$.

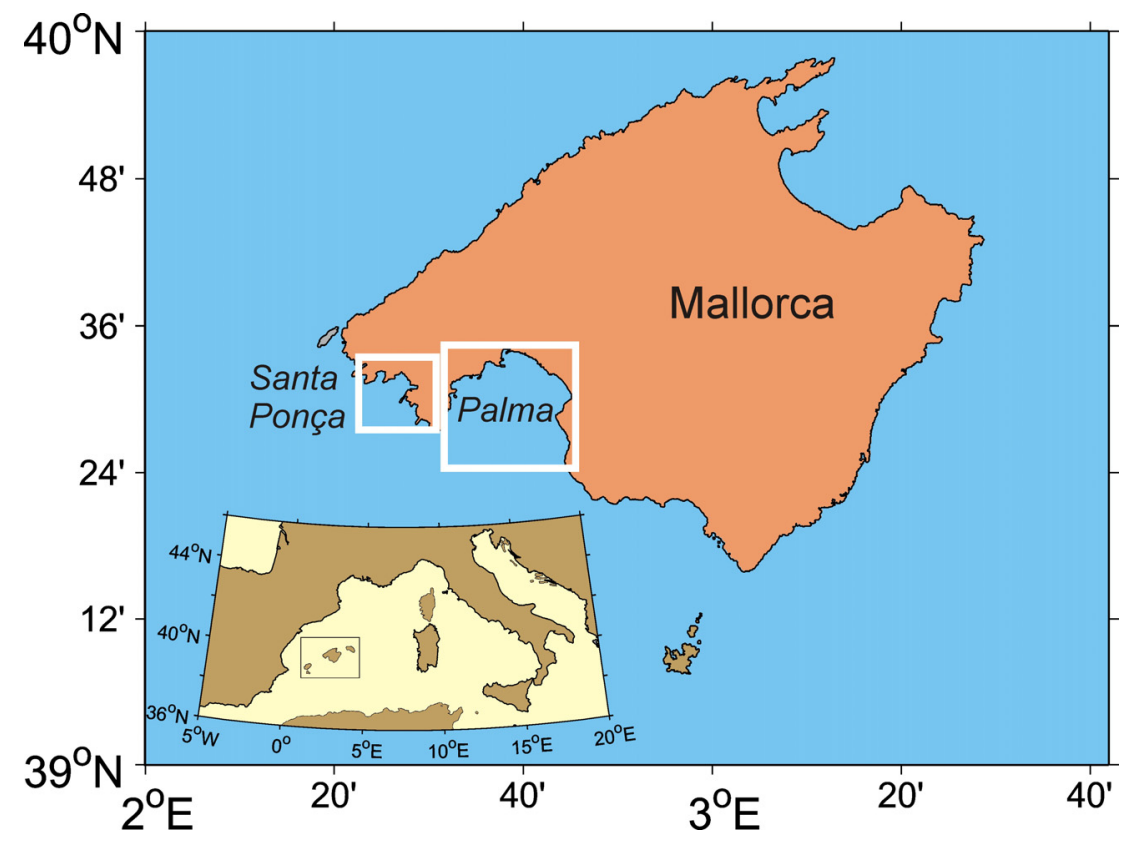

Figure 1: $\quad$ Map of Mallorca indicating the location of Palma and Santa Ponça Bays.

\section{Results and discussion}

A total amount of $206,758 \mathrm{~kg}$ of floating debris was collected during the summer 2005 in the waters of the Balearic Islands, 13\% corresponding to the material collected in Palma Bay and $2 \%$ in Santa Ponça. Palma is the most polluted area of the archipelago; however, similar amounts of litter were collected in other areas with lower human pressure (i.e. Pollença, in the northern part of the island). Monthly variation of collected litter reveals a similar trend during the 
first three months of the survey but, strikingly, large variations are observed in September in the bay of Palma (Figure 2). These variations are attributed to an increase in the inputs of natural wood of terrestrial origin during a storm that took place between September $7^{\text {th }}$ and $9^{\text {th }}$. Indeed, the highest precipitations of 2005 were recorded during this month (Figure 3). The larger extent of Palma watershed, more than six-fold that of Santa Ponça, may favour the arrival of important amounts of rests of vegetation to this coastal area.

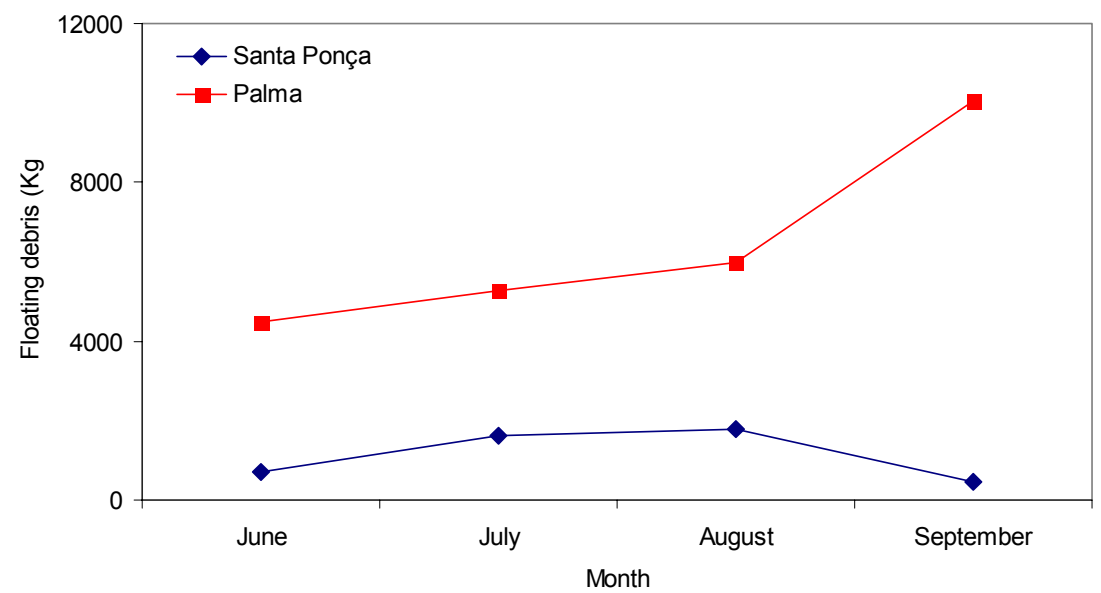

Figure 2: Variation of the amount of floating debris collected in the bays of Palma and Santa Ponça during the 2005 summer cleaning campaign.

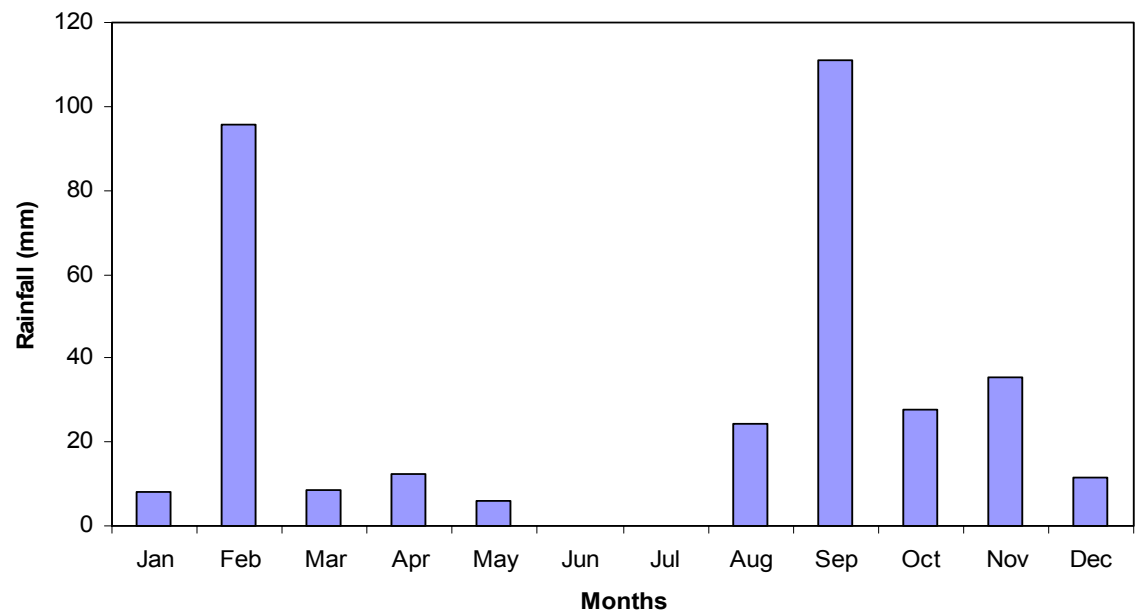

Figure 3: 2005 Monthly values of rainfall at Palma Airport. 
The classification of debris into different types of materials shows that wood and its derivates is the most important debris (in weight) in the four months in Palma followed by plastics (Table 1). These two materials account in this bay for between 73 and $86 \%$ of the total weight. Similarly, these materials contribute to an average of $66.3 \pm 3 \%$ of the litter in Santa Ponça, where seaweeds and other materials of heterogeneous nature become more important. The amount of organic matter collected at Santa Ponça is also remarkably higher with the exception of the value in Palma for august, when a large sperm whale rest $(5 \mathrm{~m}$ long) was collected. In addition, a marine turtle (Caretta caretta) was found. It should be noted that although our data referred in terms of weight following the standard procedure of local authorities, when the values are interpreted in terms of collected items plastics become most important. Most of these items (70\%) where identified as being of local origin (nearby supermarkets and shops) and presented a low degree of degradation. Wind transport could be an important source of litter to coastal waters, particularly in the case of plastics.

Table 1: Monthly variation in the percentage of floating debris collected at Palma and Santa Ponça (measurements in kg).

\begin{tabular}{|l|c|c|c|c|}
\hline & June & July & August & September \\
\hline PALMA BAY & $\%$ & $\%$ & $\%$ & $\%$ \\
\hline Wood & 56.2 & 42.4 & 39.7 & 73 \\
\hline Organic matter & 3.7 & 3 & 12.3 & 5.4 \\
\hline Plastic & 29.7 & 33.3 & 33.1 & 12.7 \\
\hline Oil & 0 & 1 & 1.1 & 0 \\
\hline $\begin{array}{l}\text { Algae and } \\
\text { seaweeds }\end{array}$ & 5 & 12 & 7.3 & 4.4 \\
\hline Other & 5.4 & 8.2 & 6.6 & 4.4 \\
\hline & June & July & August & September \\
\hline SANTA PONÇA & $\%$ & $\%$ & $\%$ & $\%$ \\
\hline Wood & 19.7 & 30.4 & 41.5 & 34.2 \\
\hline Organic matter & 9.4 & 9.8 & 8.4 & 7.5 \\
\hline Plastic & 47.2 & 36.2 & 20.3 & 35.8 \\
\hline Oil & 0 & 0 & 0 & 0 \\
\hline $\begin{array}{l}\text { Algae } \\
\text { seaweeds }\end{array}$ & 12.4 & 11.8 & 10.3 & 16.6 \\
\hline Other & 11.4 & 11.8 & 19.5 & 5.8 \\
\hline
\end{tabular}

As indicated by the wind rose of Palma Airport, winds blowing from the first and third quadrant are predominant during summer (Figure 4). Wind vectors from SSW and SW are related to the sea breeze in the bay, that rarely exceeds 7 $\mathrm{m} / \mathrm{s}$ (Werner et al. [11]). Winds from the NNE and ENE are generally milder $(<5$ $\mathrm{m} / \mathrm{s}$ ) and associated with the land breeze component. However, periodical strong Tramontana events also blow from this direction.

The GPS positions of the cleaning boats corresponding to the above mentioned predominant wind directions have been analyzed for the two study 
sites. As shown in the density maps, cleaning activities concentrate in a short portion of the coast, usually in transects running around harbours (Figure 5). Cleaning boats focus their activity in small embayments, where the geomorphology favours the concentration of debris. This is clearly seen in the embayment located to the west of Palma (Cala Nova), and it is particularly remarkable in the west zone of Santa Ponça (Camp de Mar). Moreover, the highest density of boat positions concentrates in the vicinity of Palma harbour, including its inner port. It is in this area where both, the metropolitan sewage and drainage systems converge. Nevertheless, their relative contribution to the total litter amount has not been established, and other sources in the area such as port activities should be considered.

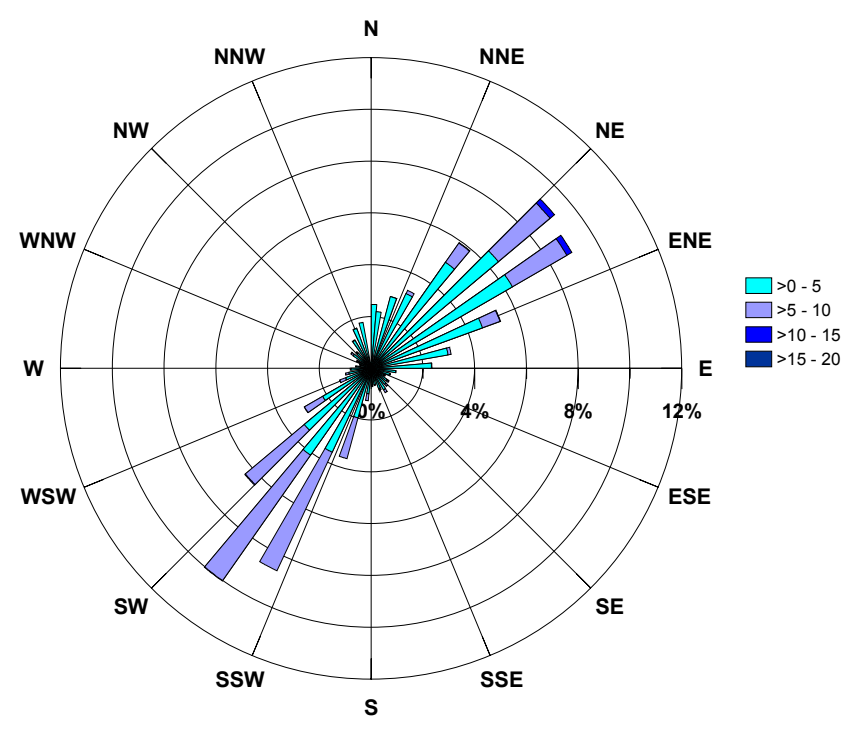

Figure 4: Wind rose for Palma Airport. Data from INM.

Regarding the wind effect, there are not important differences between the analyzed wind directions. Two plausible explanations could explain the low variability observed: (1) debris is collected close to its source and therefore there is no time for wind induced litter dispersal; (2) boats concentrate their cleaning activities based on the skippers experience and only change their routes when other sources of information are provided (i.e. airborne observations, user's complaints). Despite these biases, some relevant features can be depicted from the cleaning routes. During SW winds at Palma, the collection of debris takes place primarily close to the harbour and to the west of the bay (Cala Nova). In the other case (NE winds) debris is more dispersed in the eastern coast of Palma and is gathered farther from the coast. This area corresponds to a long $(4.5 \mathrm{~km})$ sandy beach known as El Arenal where, when the winds blow from the sea, cleaning activities concentrate closer to the shoreline and should be basked by 
land-based operations. This wind effect is also notable in the Bay of Santa Ponça, where there is a notable spreading under northeasterly wind conditions and a higher cleaning effort at the east of the bay during SW wind conditions.
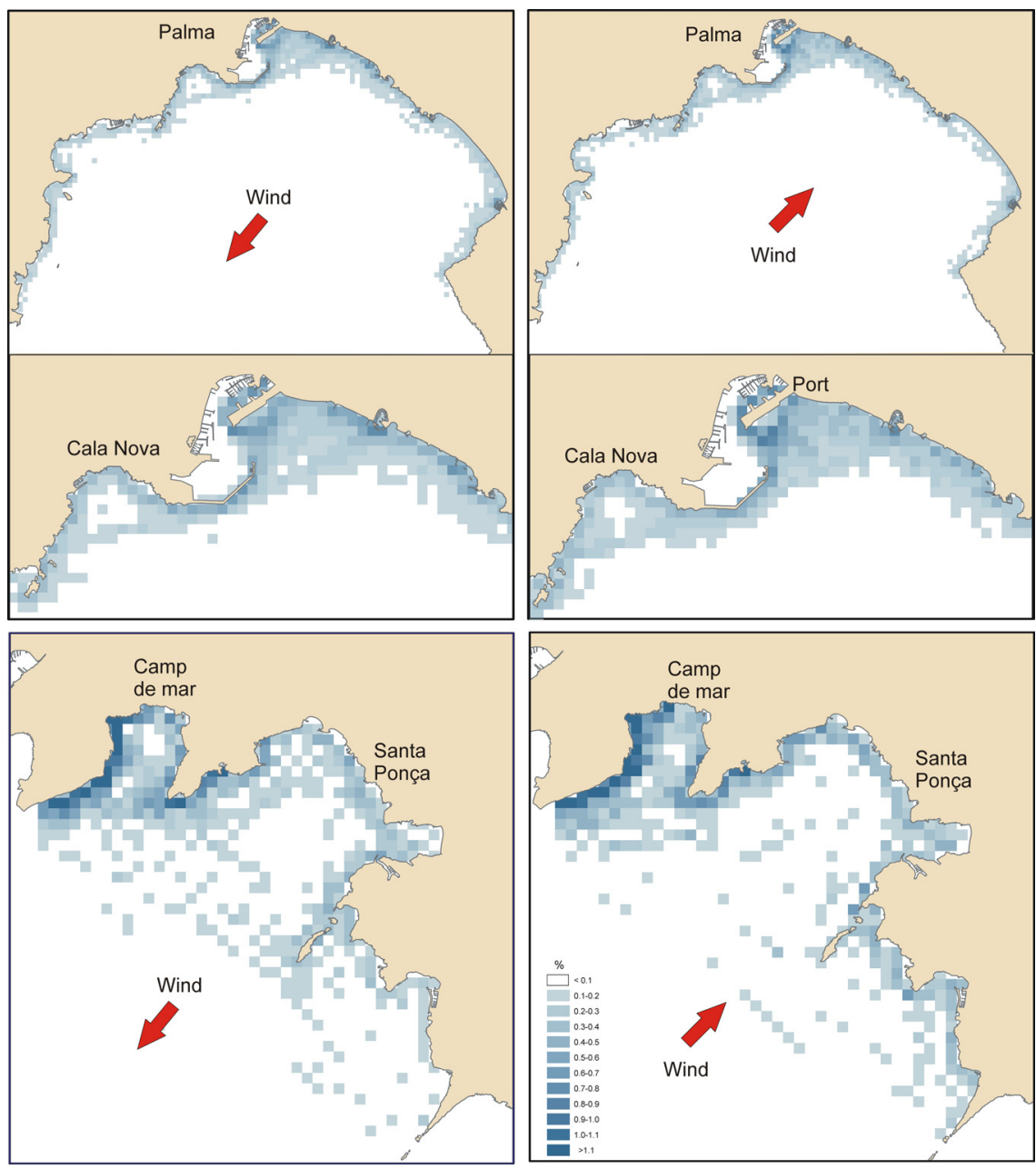

Figure 5: Standardized density maps of cleaning boats positions.

Furthermore, when observing (Figure 6) the quantities of flotsam collected under each of the wind scenarios, in both bays the influence of winds blowing from directions 1 and 3 produces a higher concentration of debris, which is reflected in the amount of it collected. As it was mentioned, the quantities in the Bay of Palma are higher than in the Bay of Santa Ponça. The lowest values were recorded under wind 4 in both bays. 


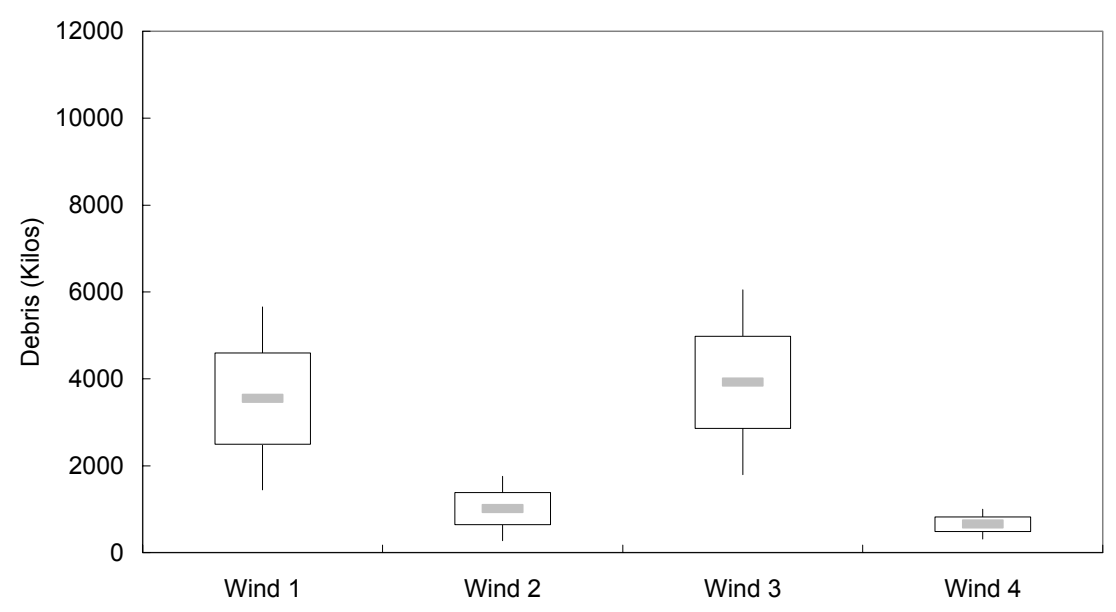

Palma

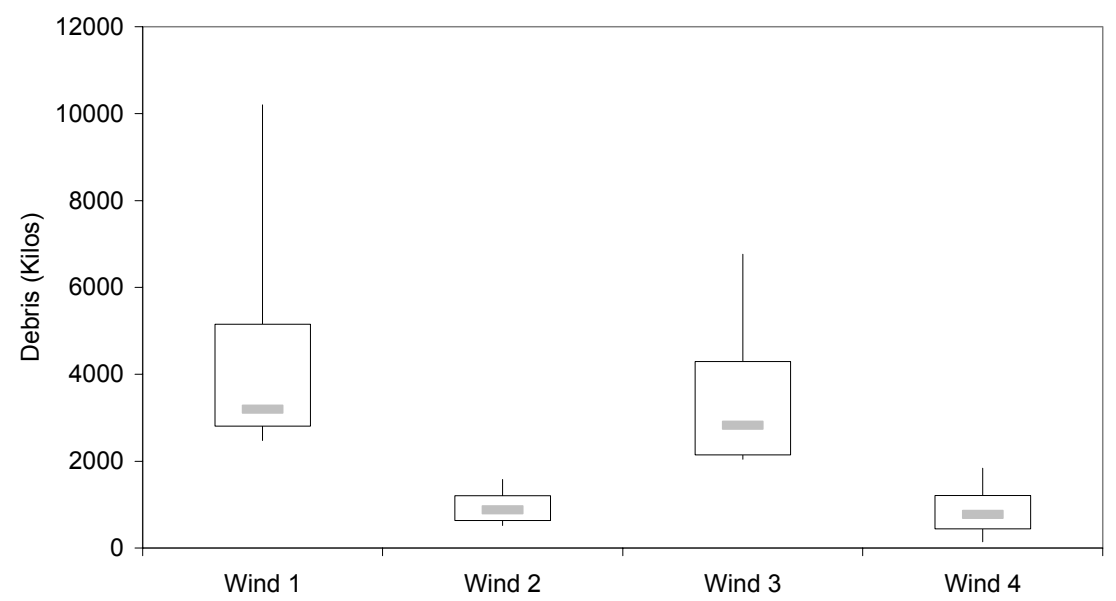

Figure 6: Amount of debris collected under different wind scenarios in the two bays studied, Santa Ponça and Palma. The grey lines represent the median values, and the vertical lines represent the maximum and minimum values.

\section{Conclusions}

The debris scenario for two bays at Mallorca has been analysed using the positions of cleaning boats. By weight, wood has been the major component of the litter collected, followed by plastics. If counting the number of items, plastics 
would be the commonest type of material. Given the high floatability of both kinds of material the wind regime on the island was analysed, showing certain effect on the distribution of the debris. However, other factors are to be thought of, as for instance the geomorphology of the area and the possible sources of the debris. In the study herein presented, local plastics had a high percentage of presence (about 70\%), which indicates how important it is to follow good disposal procedures.

\section{Acknowledgements}

This work was carried out as part of the program 'Convenio para la evaluación y monitorización de la calidad de las agues costeras de las Islas Baleares' financed by the Conselleria de Medi Ambient of the Balearic Government. We are indebted to Joan Vallespir and Maurici Ruiz for assistance in GIS based data processing.

\section{References}

[1] Laist, D. W., Overview of the Biological Effects of Lost and Discarded Plastic Debris in the Marine Environment. Marine Pollution Bulletin, 18, No. 6B, pp. 319-326, 1987.

[2] Pruter, A. T., Sources, Quantities and Distribution of Persistent Plastics in the Marine Environment. Marine Pollution Bulletin, 18, No. 6B, pp. 305310, 1987.

[3] Galgani, F., Leaute, J. P., Moguedet, P., Souplets, A., Verin, Y., Carpentier, A., Goraguer, H., Latrouite, D., Andral, B., Cadiou, Y., Mahe, J. C., Poulard, J. C. \& Nerisson, P., Litter on the Sea Floor Along European Coasts. Marine Pollution Bulletin, 40, No. 6, pp. 516-527, 2000.

[4] Shaw, D. G. \& Mapes, G. A., Surface Circulation and the Distribution of Pelagic Tar and Plastic. Marine Pollution Bulletin, 10, pp. 160-162, 1979.

[5] Thiel, M., Hinojosa, I., Vásquez, N. \& Macaya, E., Floating marine debris in coastal waters of the SE-Pacific (Chile). Marine Pollution Bulletin, 46, pp. 224-231, 2003.

[6] Abu-Hilal, A.H. \& Al-Najjar, T., Litter pollution on the Jordanian shores of the Gulf of Aqaba (Red Sea). Marine Environmental Research, 58, pp. 39-63, 2004.

[7] Vauk, G. J. \& Schrey, E., Litter pollution from ships in the German Bight. Marine Pollution Bulletin, 18, No. 6B, pp. 316-319, 1987.

[8] Dixon, T. J. \& Dixon, T. R., Marine Litter Surveillance. Marine Pollution Bulletin, 12, No. 9, pp. 289-295, 1981.

[9] Tomás, J., Guitart, R., Mateo, R. \& Raga, J. A., Marine debris ingestion in loggerhead sea turtles, Caretta caretta, from the Western Mediterranean. Marine Pollution Bulletin, 44, pp. 211-216, 2002.

[10] Basterretxea, G., Garcés, E., Jordi, A., Masó, M \& Tintoré, J., Breeze conditions as a favoring mechanisms of Alexandrium taylori blooms at a 
562 Management of Natural Resources, Sustainable Development and Ecological Hazards

Mediterranean beach. Estuarine, Coastal and Shelf Science, 62, pp. 1-12, 2005.

[11] Werner, F. E., Viúdez, A. \& Tintoré, J., An explanatory numerical study of the currents off the southern coast of Mallorca including the Cabrera Island complex. Journal Marine Systems, 4, pp. 45-66, 1993. 